\title{
Shipboard identification of fish eggs and larvae by multiplex PCR, and description of fertilized eggs of blue marlin, shortbill spearfish, and wahoo
}

\author{
J. R. Hyde ${ }^{1,2, *}$, E. Lynn ${ }^{2}$, R. Humphreys Jr. ${ }^{3}$, M. Musyl ${ }^{4}$, A. P. West ${ }^{5}$, R. Vetter $^{2}$ \\ ${ }^{1}$ Scripps Institution of Oceanography, 9500 Gilman Drive, La Jolla, California 92093-0203, USA \\ ${ }^{2}$ Southwest Fisheries Science Center, National Marine Fisheries Service, NOAA, 8604 La Jolla Shores Drive, La Jolla, \\ California 92037, USA \\ ${ }^{3}$ Pacific Islands Fisheries Science Center, National Marine Fisheries Service, NOAA, 2570 Dole Street, Honolulu, \\ Hawaii 96822, USA \\ ${ }^{4}$ Pelagic Fisheries Research Program, Joint Institute for Marine and Atmospheric Research, University of Hawaii, \\ Honolulu, Hawaii 96822, USA \\ ${ }^{5}$ University of Technology Sydney, Westbourne St. Gore Hill, New South Wales 2065, Australia
}

\begin{abstract}
The study of the early life history of large, open-ocean pelagic fishes such as tunas and billfish, and the identification of spawning and nursery habitats, has been extremely difficult as these animals are intrinsically rare, highly migratory, and difficult to study in captivity. Traditional methods such as the assembling of a developmental series of life stages, or the culturing of unknown eggs and larvae to a point where they can be identified, has not been easy or fruitful for many pelagic species. The discovery of a putative spawning 'hot spot' off the Kona coast of Hawaii, coupled with the development of shipboard approaches to real time identification and adaptive sampling of eggs, may provide new approaches and insights into the spawning ecology and reproductive biology of these highly valuable but poorly known species. Here we report the use of a shipboard PCR based assay to differentiate species of istiophorid billfish larvae and identify eggs of istiophorid and xiphiid billfish, coryphaenid dolphinfish, and wahoo. A species-specific multiplex PCR assay was designed to amplify a single, unique size fragment of the mitochondrial cytochrome $b$ gene for all 6 species of Indo-Pacific billfish, both dolphinfish, and the monospecific wahoo. A boiling technique used to extract DNA from larval eye tissue or an individual egg, combined with a single-step PCR assay and agarose electrophoresis, allowed species identification within $3 \mathrm{~h}$ of sample acquisition. This nearly real-time identification method for morphologically indistinguishable eggs and larvae provides an opportunity to employ adaptive sampling methods to increase sampling efficiency and will help in determining the spatial and temporal dimensions of spawning and nursery habitats offshore. This study describes the occurrence of blue marlin, dolphinfish, shortbill spearfish, swordfish and wahoo off the Kona coast by molecular approaches, and it provides the first description of the eggs of blue marlin, shortbill spearfish and wahoo.
\end{abstract}

KEY WORDS: Dolphinfish · Genetic identification · Species-specific PCR · Marlin · Sailfish · Spearfish • Swordfish $\cdot$ Wahoo

Resale or republication not permitted without written consent of the publisher

\section{INTRODUCTION}

Identification of eggs and early stage larvae is an important tool for understanding the ecology and early life history of fishes (Moser \& Boehlert 1991, Moser \& Smith 1993, Lo et al. 2001). This knowledge is of particular importance when it can be used for improving the management of harvested species (Moser et al. 2000), or assessing risks to spawning habitats due to anthropogenic factors such as ozone depletion and UV damage (Vetter et al. 1999). In many cases, morphological criteria alone are insufficient to 
separate early life stages of closely related species. Of particular importance is the identification of morphologically indistinguishable (cryptic) eggs and larvae of commercially important species.

Research on billfish (Istiophoridae and Xiphiidae) has been conducted primarily on adults, as they are readily obtainable from commercial and recreational fisheries. Conventional tagging studies of adult billfish and tunas have shown that they are highly migratory and capable of trans-oceanic movements (Block et al. 2001, Sedberry \& Loefer 2001). However, there is evidence for philopatry in tunas (Block et al. 2001). Data from pop-off satellite archival tags suggests that spawning areas for Atlantic bluefin tuna, and perhaps for other large pelagic fish, can be geographically restricted and limited in number (Lutcavage et al. 1999, Block et al. 2001). These spawning areas are critically important for management to protect from over-harvesting, habitat alteration and pollution. To better understand the reproductive behavior of billfish, temporal and spatial patterns of the distribution of eggs and larvae warrant further investigation.

Billfish larvae are usually rare in ichthyoplankton samples. Moreover, identification of particular species usually is conducted months or years after the preserved samples are sorted. If samples can be identified quickly on board, adaptive sampling efforts could be used to collect additional samples and better define the spatial and temporal distribution of spawning areas. Identification to species for istiophorid larvae is difficult when using traditional meristic and morphological characters (Collette et al. 1984, Nishikawa \& Rimmer 1987, Nishikawa \& Ueyanagi 1992). Post-flexion billfish larvae captured in surface plankton samples are well developed and capable of swimming and predation. Their dispersal capacity complicates the delineation of the original spawning areas. As eggs are short lived and can be viewed as passive particles, they may be better indicators of spawning areas. Fertilized eggs and larvae have been described for swordfish Xiphias gladius (Sanzo 1922, Yasuda et al. 1978), and the Mediterranean spearfish Tetrapturus belone (Sparta 1953). Fertilized eggs of all 5 species of Indo-Pacific istiophorids are not described in the literature. Consequently, a genetic assay was designed to discriminate among the 6 species of Indo-Pacific billfish. The 2 dolphinfish Coryphaena equiselis and C. hippurus and the wahoo Acanthocybium solandri commonly co-occur with billfish and are often taken along with billfish in recreational and commercial fisheries. These species were included in our study, to provide further insights into the degree of inter-specific overlap in pelagic fish spawning behavior and spawning habitat.
DNA based assays are increasingly used to identify organisms and investigate larval life history and ecology of a variety of vertebrates and invertebrates (Powers 1993, Burton 1996). Currently the most common method used for identification of marine fish larvae, amenable to both frozen and ethanol preserved specimens, is the polymerase chain reaction (PCR) restriction fragment length polymorphism (RFLP) procedure applied to mitochondrial and/or nuclear genes (Graves et al. 1990, Bartlett \& Davidson 1991, Chow \& Inoue 1993, Chow et al. 1993, Daniel \& Graves 1993, Chow 1994, Graves \& McDowell 1995, Tagliavini et al. 1995, Innes et al. 1998, Lindstrom 1999, Cordes et al. 2001, Gharrett et al. 2001, McDowell \& Graves 2002, Welsford et al. 2004). PCR-RFLP techniques for identifying billfish species have been applied to ethanol preserved larvae (Chow 1994, Innes et al. 1998, McDowell \& Graves 2002). These methods function well but depend on multiple restriction treatments after PCR amplification. This poses a problem when identification is needed quickly and with samples that may have a low quantity of, or degraded DNA. Shipboard identification of larval billfish using the method described by Chow (1994) was conducted by the authors on previous research cruises, but with limited success $(51.9 \%$ succesful identification in the field and $84.7 \%$ in a land based laboratory). Application of this method required roughly $12 \mathrm{~h}$ of throughput for species identification.

A new method was developed to improve identification and reduce labor and time. Following RochaOlivares (1998), Hare et al. (2000), Hill et al. (2001), Noell et al. (2001) and Shivji et al. (2002), a multiplex species-specific PCR method was designed to produce a single band of unique size for each of the 6 Pacific billfish species, 2 dolphinfishes, and the wahoo. This method involves only a single PCR step and is relatively inexpensive (US\$1.19 per sample; RochaOlivares 1998; US\$0.50 per sample: Hare et al. 2000), and identification of samples is completed within $3 \mathrm{~h}$. This rapid shipboard identification allows researchers to adapt sampling protocols for more efficient study of egg and larval distribution.

\section{MATERIALS AND METHODS}

Design of species-specific primers. Tissue samples (white muscle) were obtained from adult billfish captured by commercial longline vessels sampled in port in Honolulu, Hawaii: blue marlin Makaira nigricans, Indo-Pacific sailfish Istiophorus platypterus, striped marlin Tetrapturus audax, shortbill spearfish Tetrapturus angustirostris, and swordfish Xiphias gladius. As black marlin $M$. indica are rare in Hawaiian waters, 
tissue samples were obtained from $\mathrm{J}$. Pepperell, Australia. Another 3 pelagic species were sampled due to their commercial and ecological importance as well as their presence in icthyoplankton samples from the study area: wahoo Acanthocybium solandri, pompano dolphinfish Coryphaena equiselis, and common dolphinfish C. hippurus. DNA was extracted using a DNeasy extraction kit (Qiagen) according to manufacturer's protocol. The mitochondrial cytochrome $b$ gene was amplified via PCR using primers Gludg-L (5'TGA CTT GAA RAA CCA YCG TTG 3') (Palumbi et al. 1991) and revThrRF (5'TCC GAC ATC TGG ATT ACA A 3') (Rocha-Olivares et al. 1999). Briefly, $50 \mu$ reaction volumes containing $(67 \mathrm{mM}$ Tris- $\mathrm{HCl}$ $\mathrm{pH} 8.8,16.6 \mathrm{mM}\left(\mathrm{NH}_{4}\right)_{2} \mathrm{SO}_{4}, 10 \mathrm{mM} \beta$-mercaptoethanol, $2 \mathrm{mM} \mathrm{MgCl} 2,800 \mu \mathrm{M}$ dNTPs, $0.4 \mu \mathrm{M}$ each primer, 2.5 units Taq DNA polymerase (New England Biolabs), and $100 \mathrm{ng}$ of DNA template) were amplified using the following temperature profile in a 9600 GeneAmp PCR System (PerkinElmer); $94^{\circ} \mathrm{C}$ (2:00 min), 35 cycles of $\left[94^{\circ} \mathrm{C}(0: 45 \mathrm{~min}), 53^{\circ} \mathrm{C}(1: 30 \mathrm{~min}), 72^{\circ} \mathrm{C}\right.$ $(1: 30 \mathrm{~min})]$, followed by $5 \mathrm{~min}$ at $72^{\circ} \mathrm{C}$. Products were electrophoresed through a $2 \%(\mathrm{w} / \mathrm{v})$ agarose gel in $1 \times$ Tris-Borate-EDTA buffer, stained with ethidium bromide and visualized via an UV-transilluminator. Reactions were processed through a QiaQuick PCR purification kit (Qiagen) to remove excess primer and unincorporated deoxynucleotides prior to cycle sequencing. Products were cycle sequenced with BigDye v.3.0 (Applied Biosystems) and analyzed on an ABI 3100 automated capillary sequencer (Applied Biosystems).

Sequences were aligned and edited using Sequencher v.4.1 software (Gene Codes). Consensus cytochrome $b$ sequences for each species have been placed in Genbank under the following accession numbers: AY319369 (Tetrapturus angustirostris) $\mathrm{n}=$ 15, AY319370 (T. audax) n = 4, AY319371 (Istiophorus platypterus) $\mathrm{n}=3$, AY319372 (Makaira indica) $\mathrm{n}=4$, AY319373 (M. nigricans) $\mathrm{n}=27$, AY319374 (Xiphias gladius) n = 18, AY895017 (Acanthocybium solandri) $\mathrm{n}=6$, AY895016 (Coryphaena equiselis) $\mathrm{n}=3$, AY895015 (C. hippurus) $\mathrm{n}=3$. Additional sequences (Finnerty \& Block 1995) were obtained from GenBank and added to our dataset. From the aligned sequences a universal forward primer was chosen to complement a set of species-specific reverse primers (Table 1). Species-specific reverse primers were designed to amplify products of different sizes (capable of separation by agarose electrophoresis), have similar melting temperature $\left(T_{\mathrm{m}}\right)$, and contain a species-specific nucleotide on the 3 ' end. As only the 6 species of Indo-Pacific billfish, 2 dolphinfish, and wahoo were included in the design of the assay and reference samples were obtained from a limited geographic area (Table 2), inter- and intraspecific genetic variability could affect the function of this assay. To test for false negative results due to DNA

Table 2. Summary of samples used to design and test multiplex PCR assay for billfish, dolphinfish and wahoo eggs

\begin{tabular}{|llcccc|}
\hline Species & Common name & Sequenced $^{\text {a }}(\mathrm{n})$ & Identified $(\mathrm{n})$ & Total & Sample location \\
\hline Acanthocybium solandri & Wahoo & 6 & 33 & 39 & Atlantic, Pacific \\
Coryphaena equiselis & Pompano dolphinfish & 3 & 7 & 10 & Pacific \\
Coryphaena hippurus & Common dolphinfish & 13 & 25 & 38 & Pacific \\
Istiophorus platypterus & Sailfish & 3 & 1 & 4 & Atlantic, Pacific \\
Makaira indica & Black marlin & 4 & 1 & 5 & Indian, Pacific \\
Makaira nigricans & Blue marlin & 27 & 338 & 365 & Atlantic, Indian, Pacific \\
Tetrapturus angustirostris & Shortbill spearfish & 15 & 93 & 108 & Pacific \\
Tetrapturus audax & Striped marlin & 4 & 26 & 30 & Pacific \\
Xiphias gladius & Swordfish & 18 & 55 & 73 & Atlantic, Pacific \\
ancludes sequence data from & Finnerty \& Block (1995) & & & & \\
\hline
\end{tabular}


extraction failure, a pair of primers is used to amplify a portion of the mitochondrial 16S ribosomal DNA (Palumbi et al. 1991). These primers are reported to work on most vertebrates and should serve well to indicate the presence of amplifiable DNA.

Collection of eggs and larvae. Larvae and eggs were collected from the neuston and upper $1 \mathrm{~m}$ using either a $1.8 \mathrm{~m}$ Isaacs-Kidd Trawl (0.505 mm mesh) or a $1.5 \mathrm{~m}$ diameter ring net fitted with a PVC cod-end (0.505 mm mesh). Sampling effort was conducted 1 to $25 \mathrm{n}$ miles off the Kona coast of Hawaii. Post-flexion billfish larvae were immediately sorted out and preserved whole in $95 \%$ un-denatured ethanol. The remainder of the sample was sorted though $2.8 \mathrm{~mm}$ and $1.0 \mathrm{~mm}$ sieves and the sample fraction retained in the $1.0 \mathrm{~mm}$ sieve was resuspended in seawater, placed on ice and subsequently sorted for eggs and preflexion larvae. Eggs between 1.0 and $2.5 \mathrm{~mm}$ in diameter were measured and digitally imaged (Nikon Coolpix 995) through a dissecting microscope (Nikon SMZ800) and then stored either individually in vials of $95 \%$ un-denatured ethanol or placed directly into a $0.2 \mathrm{ml}$ PCR tube containing $150 \mu \mathrm{l}$ of $10 \%$ Chelex 100 resin (Bio-Rad Laboratories) in de-ionized water.

DNA extraction. Ethanol fixed samples were briefly rinsed with distilled water and blotted dry on absorbent paper. The entire egg was used for DNA extraction; for larvae, the right eyeball was removed, using sterile forceps and placed into a $0.2 \mathrm{ml}$ PCR tube containing $150 \mu \mathrm{l}$ of $10 \%$ Chelex 100 resin (BioRad Laboratories) in de-ionized water. Forceps were decontaminated between samples by immersion in a $10 \%$ bleach solution followed by rinsing with distilled water. DNA was extracted by placing the sample containing tubes, along with a no tissue negative control tube, into a PTC-150 thermal-cycler (MJ Research). Samples were heated to $60^{\circ} \mathrm{C}$ for $20 \mathrm{~min}$, then $103^{\circ} \mathrm{C}$ for $25 \mathrm{~min}$, and allowed to cool to room temperature. At this point, the tubes were centrifuged briefly to remove condensation and stored at $4^{\circ} \mathrm{C}$ pending genetic analysis.

Amplification at sea. To maximize throughput, standardize reactions and reduce work while at sea, a ready-made PCR cocktail was used, Platinum PCR Supermix (Invitrogen). This reaction cocktail was mixed with bovine serum albumin (BSA) (Sigma Aldrich), the universal cytochrome $b$ primer, the 9 species-specific primers, and 2 positive control primers to a final concentration of $0.5 \mu \mathrm{M}$ for each primer, $0.5 \mathrm{mg}$ $\mathrm{ml}^{-1} \mathrm{BSA}$, and stored at $4^{\circ} \mathrm{C}$ until needed.

Prior to amplification, $9.5 \mu$ l of the Supermix-primerBSA combination was aliquoted into strips of $0.2 \mathrm{ml}$ PCR tubes. For DNA template, $1.0 \mu \mathrm{l}$ of supernatant from the Chelex extraction was added to the appropriately labeled tube containing the PCR cocktail. Every set of samples assayed also included 1 tube that received supernatant from a Chelex extraction that contained no sample, serving as a negative control to assay for false positive reactions due to DNA contamination of the reagents. Amplification was performed in a PTC-150 thermal-cycler (MJ Research) with the following parameters: $94^{\circ} \mathrm{C}(2: 00 \mathrm{~min}), 35$ cycles of $\left[94^{\circ} \mathrm{C}\right.$ $\left.(0: 10 \mathrm{~min}), 56.5^{\circ} \mathrm{C}(0: 30 \mathrm{~min}), 72^{\circ} \mathrm{C}(0: 30 \mathrm{~min})\right]$, and $72^{\circ} \mathrm{C}$ for $3 \mathrm{~min}$.

Following amplification, $30 \mu \mathrm{l}$ of diluted loading buffer $(10 \%$ glycerol, $10 \mathrm{mM}$ Tris $\mathrm{HCl} \mathrm{pH} \mathrm{8.1,} 1 \mathrm{mM}$ EDTA, $0.0005 \%$ bromophenol blue, $0.0005 \%$ xylene cyanol) was added directly to the PCR reactions. From this, $20 \mu \mathrm{l}$ was loaded directly onto a $4 \%$ Agarose (High Resolution) E-Gel (Invitrogen) and electrophoresed for $30 \mathrm{~min}$ at $60 \mathrm{~V}$. The E-Gel system, though relatively expensive, was used because it requires no aqueous buffer and reduces ethidium bromide waste, which are both hazards aboard a rolling ship. Additionally, the pre-cast E-Gels reduced work on board and improved standardization of results. Images were captured using a Polaroid camera and UV-transilluminator.

Analysis. E-gels were run with 1 lane containing a standard ladder composed of pooled fragments amplified from reference specimens for each assayed species. Gel images were scored by eye and identification of eggs and larvae were determined by matching product band size with those in the standard lane (see Fig. 1). Samples that failed to produce amplification of the $16 \mathrm{~S}$ control fragment and any of the speciesspecific fragments were considered DNA extraction failures and were re-extracted if sufficient tissue was available.

\section{RESULTS}

From the May 2003 cruise, 76 istiophorid larvae were collected and analyzed. All 76 samples produced bright single-banded PCR products and were identified to species. These samples were composed of 2 species: 72 shortbill spearfish Tetrapturus angustirostris and 4 blue marlin Makaira nigricans. Swordfish Xiphias gladius larvae were not analyzed, as they are readily identified by their morphology. An additional cruise conducted during July 2004 saw 215 istiophorid larvae analyzed. Similar to the previous cruise the sample was composed of 2 species, but with different relative abundance: 10 shortbill spearfish and 191 blue marlin. The remaining 14 larvae failed to produce amplifications of both the control $16 \mathrm{~S}$ and speciesspecific fragments and were deemed DNA extraction failures. Overall success rate of istiophorid larval identification for these 2 cruises was $95.2 \%$. 


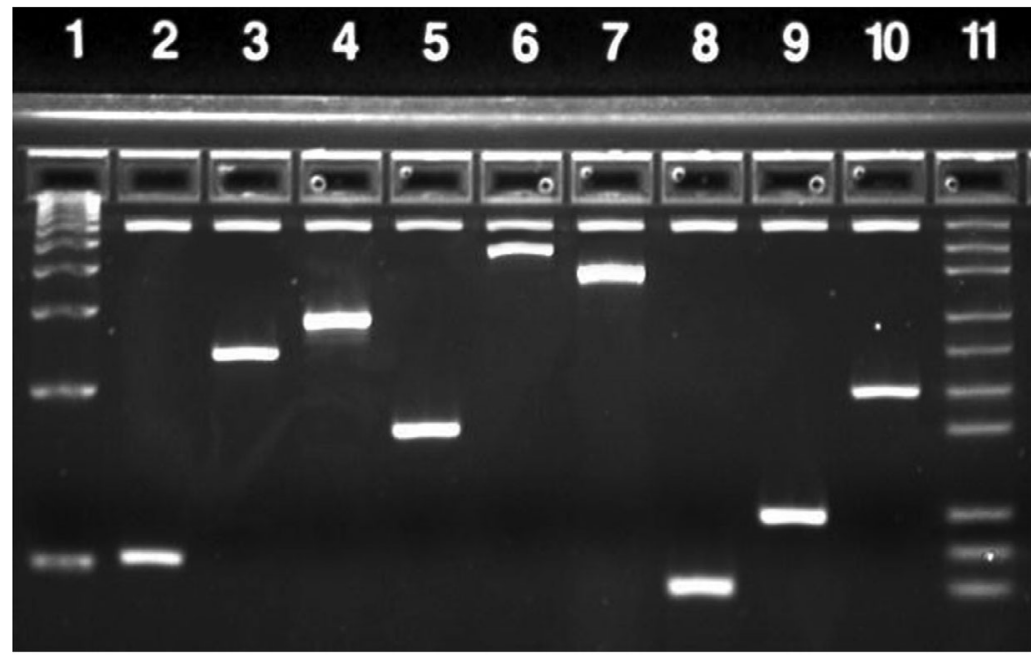

Fig. 1. Multiplex species-specific PCR products from samples processed on board ship. (1) 100 bp DNA standard; (2) swordfish; (3) blue marlin; (4) shortbill spearfish; (5) striped marlin; (6) sailfish; (7) black marlin; (8) wahoo; (9) common dolphinfish; (10) pompano dolphinfish; (11) ladder composed of pooled PCR product from all assayed species: 16S rRNA control $632 \mathrm{bp}$, sailfish $463 \mathrm{bp}$, black marlin 388 bp, shortbill spearfish 287 bp, shortbill blue marlin $239 \mathrm{bp}$, pompano dolphinfish $199 \mathrm{bp}$, striped marlin $169 \mathrm{bp}$, common dolphinfish 119 bp, swordfish 104 bp, wahoo 90 bp)

As eggs for billfish from the Pacific have not previously been described, all eggs within the size range of 1.0 to $2.5 \mathrm{~mm}$ were initially extracted and subjected to PCR amplification. By comparing positive results to digital images and measurements of these eggs we were able to refine our sorting criteria and focus on pigmented eggs within the size range of 1.0 to $2.0 \mathrm{~mm}$.

From the May 2003 cruise, 148 eggs were subjected to genetic identification via the multiplex speciesspecific PCR protocol. Of these, 54 eggs were identified as swordfish, 12 as shortbill spearfish, 8 as common dolphinfish, 3 as wahoo, 2 as blue marlin, and 1 as pompano dolphinfish. After the cruise, in the laboratory, the cytochrome $b$ gene from each PCR identified egg was sequenced as previously described to verify identification. Amplification of cytochrome $b$ was unsuccessful for the 2 PCR identified blue marlin eggs, so the identification could not be verified. Of the 12 tentatively identified shortbill spearfish eggs, 4 were found to be false positives. Review of these samples showed that PCR product bands were weak and that erroneously low annealing temperatures were run on these assays, thereby compromising the specificity of the assay. These assays were then re-run at the correct annealing temperature and no false positives were detected.

All samples analyzed onboard during the May 2003 cruise were originally tested without the 16S control primers and species-specific primers for both dolphinfishes and wahoo. These samples were re-assayed after the cruise with the additional primer sets under the conditions described. Results reported here reflect the data from the second analysis. No differences were found between either method with the following exceptions: (1) individuals of the 3 additional species (common dolphinfish, pompano dolphinfish and wahoo) were identified, (2) the 2 blue marlin eggs originally identified by PCR failed to produce both species and control bands, suggesting that the DNA had been excessively degraded, and (3) no false positives were discovered.

During the July 2004 cruise 83 eggs were subjected to PCR identification. Of these, 10 were identified as swordfish, 8 as blue marlin, 5 as shortbill spearfish, 3 as pompano dolphinfish, and 1 as wahoo. As before, these samples were sequenced to verify identification. Though 47 eggs were visually identified as swordfish, only a sub-sample of 10 were tested using the PCR assay, and the remainder were preserved in $10 \%$ neutral buffered formalin for use as reference samples.

After the cruises, a sub-sample of eggs that appeared similar in appearance and size to those identified with this assay were subjected to PCR amplification with a universal set of cytochrome $b$ primers, sequenced and edited as previously described. These were compared to GenBank sequences using the BLAST algorithm (http://ncbi.nih.gov/blast) and determined not to be any of the target species. Most eggs could not be accurately identified to species due to the lack of sufficiently similar published sequences. One egg was found to match up with the milkfish Chanos chanos and 6 eggs showed similarity to GenBank sequences of Echeneis naucrates, suggesting these eggs were likely from another echeneid.

\section{Descriptions of billfish eggs}

\section{Tetrapturus angustirostris}

Fertilized eggs from Tetrapturus angustirostris have not been described in the literature. Unfertilized eggs from 'running-ripe' females are relatively colorless and spherical, ranging from 1.30 to $1.60 \mathrm{~mm}$ (mean: $1.40 \mathrm{~mm}$ ) in diameter (Nakamura 1985). In samples taken during the 2 cruises, fertilized eggs ranged in diameter from 1.30 to $1.50 \mathrm{~mm}(1.37 \pm 0.06 \mathrm{~mm}$, mean $\pm \mathrm{SD} ; \mathrm{n}=14)$. Yolk sac pigmentation of early stage eggs seems limited to 2 series of melanophores on either side of the developing embryo (Fig. 2A,B). The dextral series has 5 or 6 


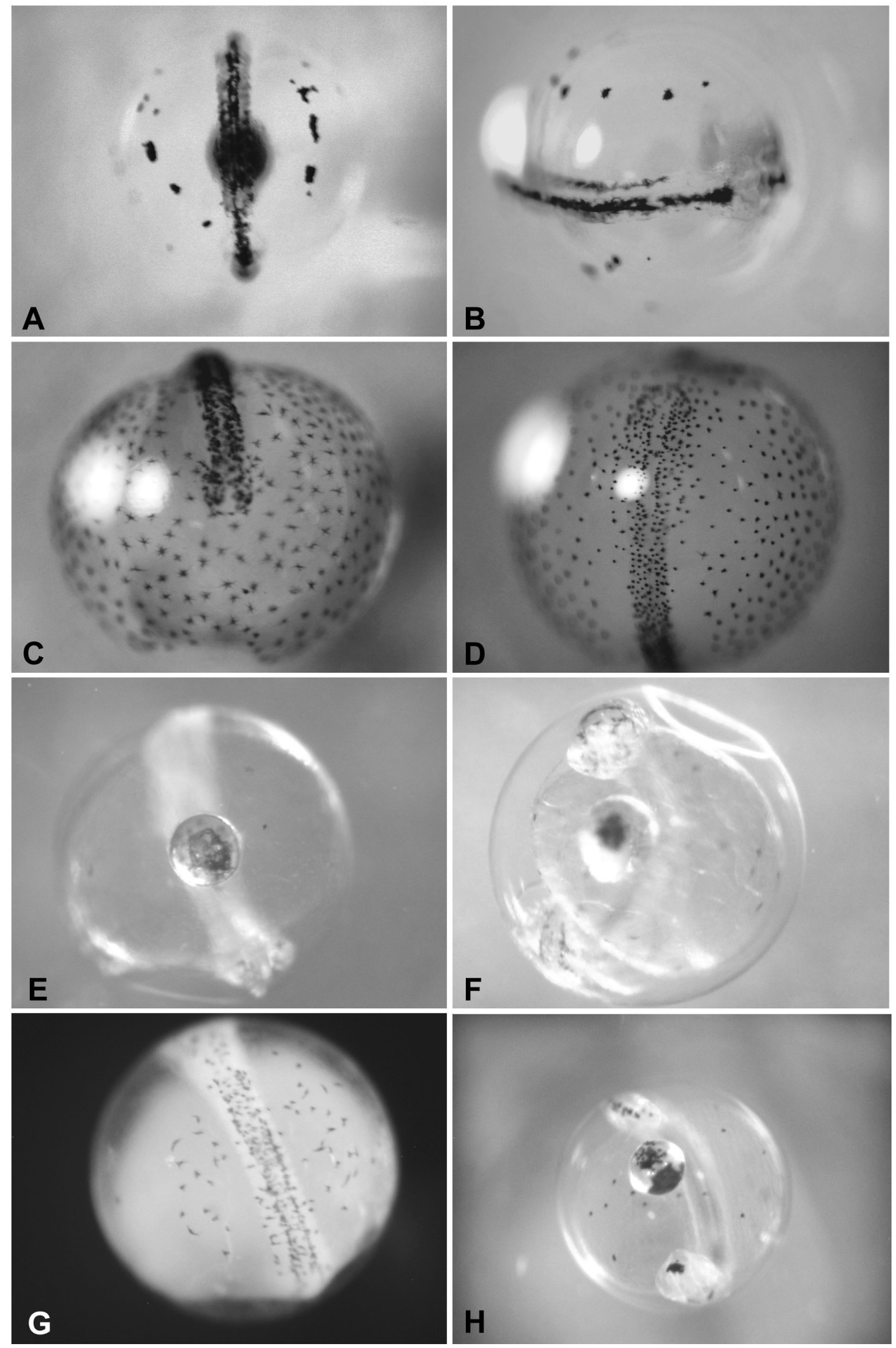

Fig. 2. Eggs of $(\mathrm{A}, \mathrm{B})$ shortbill spearfish Tetrapturus angustirostris, $(\mathrm{C}, \mathrm{D})$ swordfish Xiphias gladius, $(\mathrm{E}, \mathrm{F})$ blue marlin Makaira nigricans, $(\mathrm{G}, \mathrm{H})$ wahoo Acanthocybium solandri 
melanophores roughly parallel to the embryo. The sinistral series of 5 or 6 melanophores originates $\sim 1 / 4$ body length caudally from the head and proceeds away from the embryo at a $\sim 45^{\circ}$ angle. Embryonic melanophores appear continuous along the notochord and on both the dorsal and ventral surfaces of the developing embryo. A single oil globule is positioned near the chorion immediately forward of the rostral end of the developing embryo. A dense patch of melanophores is present on the oil globule's surface closest to the chorion.

\section{Xiphias gladius}

Fertilized eggs of Xiphias gladius were first described by Sanzo (1922) and further described by Yasuda et al. (1978) based on eggs collected in the Mediterranean, and we think it prudent to describe eggs found in the Pacific: swordfish eggs in this study measured in diameter 1.50 to $2.00 \mathrm{~mm}(1.71 \pm 0.10 \mathrm{~mm}$, mean $\pm \mathrm{SD}_{i} \mathrm{n}=67$ ), confirming the described size of 1.6 to $1.8 \mathrm{~mm}$. Fresh specimens in seawater appeared transparent except for dark melanophores on the yolk sac and developing embryo (Fig. 2C). When preserved in $95 \%$ ethanol, both yolk sac and embryo turn opaque white and the melanophores appear to constrict in size (Fig. 2D). Melanophores are distributed uniformly over the surface of the yolk sac. Embryonic melanophores are distributed along the entire length of the dorsal side of the embryo and are smaller and more densely packed than those on the yolk sac.

\section{Makaira nigricans}

Fertilized eggs of Makaira nigricans have not been reported in the literature. Unfertilized eggs from 'running-ripe' females are relatively colorless and spherical, ranging from 0.8 to $0.9 \mathrm{~mm}$ in diameter, with a single yellow oil globule (Nakamura 1985). In samples taken during the 2 cruises, fertilized eggs ranged in diameter from 1.24 to $1.30 \mathrm{~mm}(1.27 \pm 0.02 \mathrm{~mm}$, mean $\pm \mathrm{SD}_{i} \mathrm{n}=8$ ). Pigmentation of early stage eggs seems restricted to a single dense patch of melanophores on the oil globule (Fig. 2E). Yolk sac pigmentation of late stage eggs consists of scattered patches of melanophores on either side of the rostral third of the developing embryo (Fig. 2F). Embryonic melanophores appear continuous along the notochord and on both the dorsal and ventral surfaces of the developing embryo though not as pronounced as in $T$. angustirostris. A single, clear oil globule is positioned near the chorion immediately forward of the rostral end of the developing embryo. A dense patch of melanophores is present on the oil globule's surface closest to the chorion with uniformly distributed melanophores surrounding the remainder of the oil globule (Fig. 2E,F).

\section{Acanthocybium solandri}

Fertilized eggs from Acanthocybium solandri have not been reported in the literature. In samples taken during the 2 cruises, fertilized eggs ranged in diameter from 1.02 to $1.06 \mathrm{~mm}\left(1.04 \pm 0.02 \mathrm{~mm}\right.$, mean $\pm \mathrm{SD}_{i}$ $\mathrm{n}=4$ ). Yolk sac pigmentation of early stage eggs consists of scattered patches of melanophores, primarily on either side of the rostral third of the developing embryo (Fig. 2G). Embryonic melanophores appear continuous along the dorsal surface of the developing embryo. A single, clear oil globule is positioned near the chorion immediately forward of the caudal end of the developing embryo. Melanophores are distributed on the surface of the oil globule primarily in 2 dense patches. (Fig. 2H)

\section{DISCUSSION}

The multiplex species-specific PCR assay has proved to be a valuable field tool for the identification of billfish, dolphinfish and wahoo eggs and larvae. The majority of larval samples were unambiguously identified to species within $3 \mathrm{~h}$ from the start of sample processing. Though 4 false positives were detected from the egg samples, this problem was attributed to inadvertently running the assay at less than optimal conditions. Re-running these samples under the correct conditions eliminated the false positives. When compared to other methods of genetic identification (e.g. PCR-RFLP), there are observed benefits of using the multiplex assay: (1) Elimination of multiple restriction digestions saves time and expense, and reduces risk of sample contamination or mix-up. (2) Due to the small size of the amplified products, amplification success rates are expected to be greater. This might allow for identification of slightly degraded samples or samples with low DNA content, as is the case with eggs. (3) The streamlining of protocols in this study makes it possible to screen large numbers of samples while maximizing cost/ benefit.

The ability to differentiate between billfish species is of particular importance in Hawaii, where 3 Pacific billfish species spawn and all 6 may co-occur, and where larvae of shortbill spearfish Tetrapturus angustirostris have predominated in recent years (R. Humphreys Jr. unpubl.). The speed of the assay provides investigators with the opportunity to improve 
sampling design and efficiency when target species are encountered.

Shipboard motion during our cruises was minimal, as calm conditions prevailed (wave heights typically $<1 \mathrm{~m}$ and wind $<10$ knots), but the use of bufferless pre-cast agarose gels and the minimal number of required processing steps makes this method applicable for use in rougher seas. Cost per sample processed on board ship by this method (US\$1.43) was slightly higher than that of other multiplex methods (\$1.19 and \$0.50; RochaOlivares 1998, Hare et al. 2000), and cheaper than the $\$ 3.13$ per sample cost of previous at-sea studies using the PCR-RFLP method of Chow (1994). The cost is primarily due to the use of pre-cast agarose gels, premixed PCR cocktail, and Polaroid film. The per sample cost can be substantially reduced by casting agarose gels at sea, assembling PCR cocktail components ourselves, and using a digital camera to document the agarose mini-gels.

Understanding the biology and population trends in large pelagic predators such as billfish is extremely difficult. These typically solitary pelagic fishes may migrate to specific spawning areas at specific times (unlike schooling pelagic species that have continuous access to suitable mates and often spawn almost continuously and over wide geographic areas). Documentation of these spawning events and locations are rare, but can be detected by occasional discovery of eggs and larvae in systematic broad-scale surveys (Lenarz \& Adams 1980). However, boundaries of spawning and nursery grounds in space and time can only be studied in detail by comprehensive sampling of the spawning site. Shipboard detection and subsequent adaptive sampling can best accomplish this. Access to living eggs and larvae of known provenance also provides opportunities for studies of natural pigmentation patterns not retained in ethanol or formalin preserved material and for experimental approaches such as the shipboard study of the effects of UV exposure or other environmental stressors on egg and larval development (Vetter et al. 1999, Browman et al. 2003).

The Kona coast of Hawaii provides a unique study site for the investigation of billfish reproduction. The oceanography in the study area is dominated by mesoscale $\left(\sim 10 \mathrm{~km}^{2}\right)$ eddies produced by the North Equatorial Current, prevailing NE trade winds, and the leeward wake produced by the island's topography (Seki et al. 2002). These eddies may act to concentrate eggs and larvae, in addition to prey items (Wolanski \& Sarenski 1997), thereby creating a productive nursery. Three species of billfish spawn concurrently in this area. The finding of eggs and pre- and post-flexion larvae over the course of several research cruises suggests that this is an important spawning and nursery habitat for these species. Logistically the site offers the unique opportunity for frequent sampling events, as ocean conditions are calm throughout much of the year. The proximity of the island to the study site also permits investigators to use small vessels to obtain large amounts of data, and this should give new insight into billfish spawning patterns and recruitment in relation to physical oceanographic features.

Future addition of other pelagic taxa to multiplex assays or DNA micro-arrays will increase our knowledge of fine-scale ecosystem composition and function. Before such studies can be conducted, genetic databases for resident species of fishes must be constructed to design specific probes. Such databases have the potential to add tremendously to the understanding of marine ecosystems and the evolution and taxonomy of their component species.

Acknowledgements. We thank the officers and crew of NOAA RV 'Townsend Cromwell' and RV 'Oscar Elton Sette' for the assistance provided to us while at sea. We greatly appreciate the generous loan of laboratory equipment by $\mathrm{C}$. LeDuc, NOAA Fisheries, La Jolla Laboratory. Dr. V. P. Buonoaccorsi provided expert training in the application of RFLP laboratory techniques. L. McNaughton provided laboratory assistance. D. Ambrose and the Southwest Fisheries Science Center's larval fish lab provided assistance with identification. Thanks to Dr. S. Somarakis, Institute of Marine Biology of Crete, for providing color photographs of Mediterranean swordfish eggs prior to our 2003 cruise.

Disclaimer. The authors and their agencies do not necessarily approve, recommend, or endorse any proprietary product or material mentioned in this publication. The views expressed herein are those of the authors and do not necessarily reflect the views of their agencies or institutions.

\section{LITERATURE CITED}

Bartlett SE, Davidson WS (1991) Identification of Thunnus tuna species by the polymerase chain reaction and direct sequence analysis of their mitochondrial cytochrome b genes. Can J Fish Aquat Sci 48:309-317

Block BA, Dewar H, Blackwell SB, Williams TD and 7 others (2001) Migratory movements, depth preferences, and thermal biology of the Atlantic bluefin tuna. Science 293: 1310-1314

Browman HI, Vetter RD, Rodriquez CA, Cullen JJ, Davis RF, Lynn E, Saint-Pierre J-F (2003) Ultraviolet (280-400 nm)induced DNA damage in the eggs and larvae of Calanus finmarchicus G. (Copepoda) and Atlantic cod (Gadus morhua). Photochem Photobiol 77:397-404

Burton RS (1996) Molecular tools in marine ecology. J Exp Mar Biol Ecol 200:85-101

Chow S (1994) Identification of billfish species using mitochondrial cytochrome b gene fragment amplified by polymerase chain reaction. Report of the 2nd ICCAT billfish workshop. Int Comm Conserv Atl Tunas XLI:549-556

Chow S, Inoue S (1993) Intra- and interspecific restriction fragment length polymorphism in mitochondrial genes of Thunnus tuna species. Bull Nat Res Inst Far Seas Fish 30: 207-224 
Chow S, Clarke ME, Walsh PJ (1993) PCR-RFLP analysis on thirteen western Atlantic snappers (family Lutjaninae): a simple method for species and stock identification. Fish Bull 91:619-627

Collette BB, Potthoff T, Richards WJ, Ueyanagi S, Russo JL, Nishikawa Y (1984) Scombroidei: development and relationships. In: Moser HG (ed) Ontogeny and systematics of fishes. Am Soc Ichthy Herpet Spec Publ 1:591-620

Cordes JF, Armknecht SL, Starkey EA, Graves JE (2001) Forensic identification of sixteen species of Chesapeake Bay sportfishes using mitochondrial DNA restriction fragment-length polymorphism (RFLP) analysis. Estuaries 24(1):49-58

Daniel LB, Graves JE (1993) Morphometric and genetic identification of eggs of spring-spawning sciaenids in lower Chesapeake Bay. Fish Bull 92(2):254-261

Finnerty JR, Block BA (1995) Evolution of cytochrome b in the Scombroidei (Teleostei): molecular insights into billfish (Istiophoridae and Xiphiidae) relationships. Fish Bull 93(1):78-96

Graves JE, McDowell JR (1995) Inter-ocean genetic divergence of istiophorid billfishes. Mar Biol 122:193-203

Graves JE, Curtis MJ, Oeth PA, Waples RS (1990) Biochemical genetics of southern California basses of the genus Paralabrax: specific identification of fresh and ethanolpreserved individual eggs and early larvae. Fish Bull 88: $59-66$

Gharrett AJ, Gray AK, Heifetz J (2001) Identification of rockfish (Sebastes spp.) by restriction site analysis of the mitochondrial ND-3/ND-4 and 12S/16S rRNA gene regions. Fish Bull 99:49-62

Hare MP, Palumbi SR, Butman CA (2000) Single-step species identification of bivalve larvae using multiplex polymerase chain reaction. Mar Biol 137:953-961

Hill RS, Allen LD, Bucklin A (2001) Multiplexed species-specific PCR protocol to discriminate four N. Atlantic Calanus species, with an mtCOI gene tree for ten Calanus species. Mar Biol 139:279-287

Innes BH, Grewe PM, Ward RD (1998) PCR-based genetic identification of marlin and other billfish. Mar Freshw Res 49:383-8

Lenarz WH, Adams PB (1980) Some statistical considerations of the design of trawl surveys for rockfish (Scorpaenidae). Fish Bull 78(3):659-674

Lindstrom DP (1999) Molecular species identification of newly hatched Hawaiian amphidromous gobiod larvae. Mar Biotechnol 1:167-174

Lo NCH, Hunter JR, Charter R (2001) Use of a continuous egg sampler for ichthyoplankton surveys: application to the estimation of daily egg production of Pacific sardine (Sardinops sagax) off California. Fish Bull 99:554-571

Lutcavage ME, Brill RW, Skomal GB, Chase BC, Howey PW (1999) Results of pop-up satellite tagging of spawning size class fish in the Gulf of Maine: do North Atlantic bluefin tuna spawn in the mid-Atlantic? Can J Fish Aquat Sci 56: 173-177

McDowell JR, Graves JE (2002) Nuclear and mitochondrial DNA markers for specific identification of istiophorid and xiphiid billfishes. Fish Bull 100(3):537-544

Moser HG, Boehlert GW (1991) Ecology of pelagic larvae and juveniles of the genus Sebastes. Environ Biol Fish 30: 203-224

Moser HG, Smith PE (1993) Larval fish assemblages of the California current region and their horizontal and vertical distributions across a front. Bull Mar Sci 53:645-671

Moser HG, Charter RL, Watson W, Ambrose DA, Butler JL, Charter SR, Sandknop EM (2000) Abundance and distribu-

Editorial responsibility: Kenneth Sherman (Contributing Editor), Narragansett, Rhode Island, USA tion of rockfish (Sebastes) larvae in the southern California Bight in relation to environmental conditions and fishery exploitation. Calif Coop Ocean Fish Investig Rep 41:132-147

Nakamura I (1985) FAO species catalog: billfishes of the world; an annotated and illustrated catalogue of marlins, sailfishes, spearfishes and swordfishes known to date. FAO Fish Synopsis 5(125)

Nishikawa Y, Rimmer DW (1987) Identification of larval tunas, billfishes and other scombroid fishes (suborder Scombroidei): an illustrated guide. CSIRO Mar Lab Rep 186

Nishikawa Y, Ueyanagi S (1992) On the larvae of the black marlin Makaira indica. Bull Nat Res Inst Far Seas Fish 29:1-7

Noell CJ, Donnellan S, Foster R, Haigh L (2001) Molecular discrimination of garfish Hyporhamphus (Beloniformes) larvae in south Australian waters. Mar Biotechnol 3:509-514

Palumbi S, Martin A, Romano S, McMillan WO, Stice L, Grabowski G (1991) The simple fool's guide to PCR,. V. 2.0. Spec Publ University of Hawaii, Department of Zoology \& Kewalo Marine Laboratory, Honolulu, HI

Powers DA (1993) Application of molecular techniques to large marine ecosystems. In: Sherman K, Alexander LM, Gold BD (eds) Large marine ecosystems: stress, mitigation, and sustainability. American Association for the Advancement of Science, Washington, DC, p 320-352

Rocha-Olivares A (1998) Multiplex haplotype-specific PCR: a new approach for species identification of the early life stages of rockfishes of the species-rich genus Sebastes Cuvier. J Exp Mar Biol Ecol 231:279-290

Rocha-Olivares A, Rosenblatt RH, Vetter RD (1999) Molecular evolution, systematics, and zoogeography of the rockfish subgenus Sebastomus (Sebastes, Scorpaenidae) based on mitochondrial cytochrome $\mathrm{b}$ and control region sequences. Mol Phylogenet Evol 11(3):441-458

Sanzo L (1922) Uova e larva di Xiphias gladius. Mem R Comit Talassogr Ital Venezia 170:1-3

Sedburry GR, Loeffer JK (2001) Satellite tracking of swordfish, Xiphias gladius, off the eastern United States. Mar Biol 139(2):355-360

Seki MP, Lumpkin R, Flament P (2002) Hawaii cyclonic eddies and blue marlin catches: the case study of the 1995 Hawaiian International Billfish Tournament. J Oceanogr 58: 739-745

Shivji M, Clarke S, Pank M, Natanson L, Kohler N, Stanhope M (2002) Genetic identification of pelagic shark body parts for conservation and trade monitoring. Conserv Biol 16:1036-1047

Sparta A (1953) Uova e larve di Tetrapturus belone Raf. (agugllia imperiale). Boll Pesca Piscic Idrobiol 8(1):58-62

Tagliavini J, Harrison IJ, Gandolfi G (1995) Discrimination between Anguilla anguilla and A. rostrata by polymerase chain reaction-restriction fragment length polymorphism analysis. J Fish Biol 47:741-743

Vetter RD, Kurtzman A, Mori T (1999) Diel cycles of DNA damage and repair in eggs and larvae of northern anchovy, Engraulis mordax, exposed to solar ultraviolet radiation. Photochem Photobiol 69:27-33

Welsford DC, Jordan AR, Smolenski AJ (2004) Description and genetic identification of the early life-stages of Notalabrus fucicola and $N$. tetricus from Tasmanian waters, Australia, with notes on their newly settled juveniles. NZ J Mar Freshw Res 38:267-277

Wolanski E, Sarenski J (1997) Larvae dispersion in coral reefs and mangroves. Am Sci 85:236-243

Yasuda F, Kohno H, Yatsu A, Ida H, Arena P, Li Greci F, Taki Y (1978) Embryonic and early larval stages of the swordfish, Xiphias gladius, from the Mediterranean. J Tokyo Univ Fish 65(1):91-97

Submitted: July 30, 2003; Accepted: June 15, 2004

Proofs received from author: January 20, 2005 